\title{
PERAN PENALARAN BAGI PEMBELAJAR HUKUM DALAM UPAYA MEMAHAMI REALITAS HUKUM
}

\author{
Aditya Yuli Sulistyawan \\ Fakultas Hukum Universitas Diponegoro \\ JI. Prof. Soedarto, S.H., Tembalang, Semarang \\ adityayuli38@gmail.com
}

\begin{abstract}
Reasoning is a thought process that departs from sensory observation which results in a number of concepts and understandings. In addition, the presence of reasoning allows one to think logically. If the law learner uses reasoning as a method of understanding the law, then to obtain a truth would be based on logical reasoning. Like law, legal reasoning can be interpreted as a way of thinking, using, developing or controlling a problem in the field of law with reason. Legal reasoning is also always influenced by certain basic thinking, which is very fundamental (fundamental). The foundation in question is the paradigm as part of philosophy. This paper will examine what is the role of reasoning to support legal arguments in understanding the law? What are the steps to understanding the legal reality? Through this paper, it can be shown that the role of reasoning is so great for law learners in an effort to understand the reality of law.
\end{abstract}

Keywords: Reasoning; Law Students; Law

\begin{abstract}
Abstrak
Penalaran adalah proses berpikir yang bertolak dari pengamatan indera yang menghasilkan sejumlah konsep dan pengertian. Dengan penalaran memungkinkan seseorang berpikir secara logis. Jika pembelajar hukum menggunakan penalaran sebagai metode dalam memahami hukum, maka untuk memperoleh suatu kebenaran tentu akan didasarkan pada akal yang logis. Sama halnya dengan hukum, penalaran hukum dapat diartikan sebagai cara berpikir, menggunakan, mengembangkan atau mengendalikan suatu masalah di bidang hukum dengan nalar. Penalaran hukum juga senantiasa dipengaruhi oleh landasan berpikir tertentu, yang bersifat sangat mendasar (fundamental). Landasan yang dimaksud adalah paradigma sebagai bagian dalam filsafat. Tulisan ini akan menelaah tentang apakah peran penalaran untuk menyokong argumentasi hukum dalam memahami hukum? Bagaimana langkah-langkah untuk memahami realitas hukum? Melalui tulisan ini, dapat ditunjukkan bahwa peran penalaran begitu besar bagi para pembelajar hukum dalam upaya memahami realitas hukum.
\end{abstract}

Kata Kunci: Penalaran; Pembelajar Hukum; Realitas Hukum

\section{A. Pendahuluan}

Negara Indonesia adalah negara hukum, selaras dengan Pasal 1 ayat (3) UUD 1945. Hal ini berarti bahwa Indonesia tidak berdasarkan kekuasaan belaka dan oleh karena itu kekuasaan 
harus tunduk pada hukum agar tidak terjadi kesewenang-wenangan. ${ }^{1}$ Dalam konteks hukum, tradisi normatif positivistik telah menjadi penuntun sebagian besar penegak hukum, pembuat hukum, pemikir hukum, bahkan juga pembelajar hukum dan juga masyarakat secara luas. Oleh karenanya, hukum sedemikian rupa harus dibuat rasional oleh pengikut paradigma positivisme ini.

Jika suatu pemahaman hukum dipengaruhi oleh aliran positivisme hukum, maka hukum akan dimaknai sebagai konsep yang seolah tunggal. Hukum dikonsepkan sebagai seperangkat peraturan yang tertulis, dibuat oleh lembaga yang berwenang, mengikat secara tegas karena dilengkapi sanksi bagi mereka yang melanggarnya. Dari hal tersebut dapat dinyatakan bahwa muruah hukum sangatlah tinggi.

Pemaknaan hukum dalam berbagai-bagai aliran dan paradigma hanya dapat dipahami jika kita mampu melihat realitas hukum sampai pada aras filsafatnya. Dengan memahami hukum hingga menembus ke ranah filsafatnya, kita akan memahami hakikat hukum. Filsafat sebagai landasan dari penalaran hukum, dalam hal ini ditempatkan sebagai kebijaksanaan dan analisis kritis atas realitas sosial (dalam hal ini adalah realitas hukum). Oleh karenanya, filsafat hukum dapat menjadi pembulat dari teori hukum, ilmu hukum dan dogmatik hukum agar tetap mengedepankan cara berpikir yang rasional dan logis guna menjamin terciptanya keadilan dan kepastian hukum. Dogmatik hukum, teori hukum dan filsafat hukum pada akhirnya harus diarahkan kepada praktik hukum. Praktik hukum menyangkut dua aspek utama, yaitu pembentukan hukum dan penerapan hukum.

Disini dapat dimengerti bahwa penalaran memiliki peran yang vital dalam memahami realitas hukum secara komprehensif dan menjaga kehormatan dari hukum itu sendiri. Karena penalaran itu akan bermuara pada praktik hukum di mana hasil dari praktik hukum tersebut akan memiliki dampak kepada masyarakat. Penalaran hukum akan mewarnai tindakan para pemikir hukum dalam bertindak, berpikir untuk mengatasi problematika hukum yang terjadi. Lantas bagaimana peran penalaran bagi para pembelajar hukum dalam upaya memahami realitas hukum tersebut? Hal inilah yang menjadi latar belakang mengapa tulisan ini dibuat.

Menyadari tidak semua mahasiswa memahami hukum secara rasional menurut aliran positivisme hukum, tulisan ini sengaja disusun untuk mencoba menyajikan sebuah pemahaman tentang peran penalaran dalam memahami hukum agar tersaji kerangka logis serta bijak dalam mengambil sikap terkait realitas hukum yang dihadapi. Tulisan ini hendak menunjukkan pentingnya menggunakan logika dan melakukan penalaran dalam memahami sekaligus menegakkan hukum. Namun, penalaran dalam memahami hukum harus dilakukan dengan

1 Nikolas Simanjuntak, 2009, Acara Pidana Indonesia Dalam Sirkus Hukum, Jakarta, Ghalia Indonesia, hlm. xiii-xxi. 
struktur berpikir yang sistematis dan runtut agar tidak menghilangkan nilai asli dari hukum itu, dalam hal ini dalam landasan berpikir positivisme hukum.

Dengan demikian, permasalahan yang ditelaah dalam tulisan ini adalah: Pertama, bagaimanakah hukum penalaran dan penalaran hukum serta bagaimana perannya bagi para pembelajar hukum; dan kedua, bagaimanakah penalaran dilakukan melalui analisis hukum dalam memahami realitas hukum? Kedua permasalahan ini akan diuraikan dalam telaah aliran positivisme hukum sebagai upaya memahami realitas hukum dengan bangunan pemikiran yang rasional atau logis. Hal ini dilakukan untuk menjamin terwujudnya objektivitas dalam hukum dan menciptakan kepastian hukum.

\section{B. Pembahasan}

\section{Pemahaman tentang Penalaran Hukum dan Hukum Penalaran}

"Bahasa hukum harus tunduk kepada hukum bahasa!", analog ini menunjukkan bahwa suatu penalaran hukum wajib tunduk pada hukum-hukum penalaran itu sendiri. Kata "hukum" dalam "hukum penalaran" dapat diartikan sebagai kumpulan dalil yang digunakan dalam proses penalaran. Hukum-hukum penalaran dipengaruhi oleh berbagai aliran-aliran yang menyajikan karakteristik penalaran menurut sudut pandang dan aspek tertentu yang satu sama lain beraneka ragam. Hukum-hukum penalaran itu muncul karena ada karakteristik dan kebutuhan khas (konteks) keilmuan dari [kelompok] ilmu yang bersangkutan. Hal ini berarti, sangat mungkin kebenarannya menjadi relatif karena harus digantungkan pada karakteristik dan konteks keilmuan dari ilmu hukum itu sendiri. ${ }^{2}$

Selain itu, penalaran dalam fungsinya sebagai kegiatan berpikir juga memiliki karakteristik tertentu. Pertama, adanya suatu pola berpikir yang luas (logis), hal inilah yang sering disebut dengan logika. Oleh karena itu, dapat dikatakan juga bahwa setiap penalaran memiliki logikanya tersendiri karena hal tersebut merupakan sebuah proses berpikir. Sehingga, berpikir secara logis dapat berarti sebagai suatu pola, dan ketentuan tertentu yang digunakan dalam proses berpikir. Maka dari itu sebuah kerangka logika dalam satu hal tertentu sangat mungkin dianggap tidak logis jika ditinjau dari kerangka lainnya. Hal inilah yang menimbulkan adanya suatu inkonsistensi dalam menggunakan pola pikir, yang akhirnya melahirkan beberapa metode pendekatan yang bermacam-macam. ${ }^{3}$

Sedangkan menurut Aristoteles, logika sendiri tidak lepas dari silogistik. la merupakan sebuah penjelasan yang dalam suatu prosesnya terkandung unsur "abstraksi/premis mayor"

\footnotetext{
Shidarta, 2013, Hukum Penalaran dan Penalaran Hukum, Yogyakarta, Genta Publishing, hlm. 31-32. Imron Mustofa, 2016, "Jendela Logika dalam Berfikir: Deduksi dan Induksi sebagai Dasar Penalaran IImiah”, Jurnal El-Banat, Vol. 6, hlm. 124-125.
} 
dan pula unsur "definisi/premis minor" yang keduanya diperlukan untuk membangun sebuah konsep yang benar sebelum menjadi proposisi. ${ }^{4}$ Proposisi inilah yang akhirnya akan bermuara pada kesimpulan. ${ }^{5} \mathrm{Hal}$ ini dikarenakan pengetahuan yang dikumpulkan manusia bukan sekadar kumpulan koleksi semata, namun ia merupakan kompilasi dari berbagai macam esensi dari fakta-fakta tersebut. ${ }^{6}$

Kedua, harus adanya sifat analistik dalam penalaran, dengan maksud ia merupakan pencerminan dari proses berpikir yang bersandar pada suatu analisa dan kerangka berpikir tertentu, dengan logika sebagai pijakannya. Analisa itu sendiri adalah kegiatan berpikir dengan langkah-langkah yang tertentu. Sehingga kegiatan berpikir tidak semuanya dilandaskan pada penalaran, ada pula yang hanya dilandaskan pada perasaan, intuisi, ataupun hal lainnya. Karena hal-hal tersebut bersifat non-analistik, yang tidak mendasarkan diri pada suatu pola berpikir tertentu. Lantas, jika manusia berpikir dengan berlandaskan logika dan analisa, maka ia akan memiliki dasar dalam setiap argumennya serta dapat mempertanggungjawabkannya. Oleh karena itu ia akan mengerti bahwa dengan teropong yang berbeda, suatu fenomena dapat menghasilkan analisa yang berbeda pula. Selain itu, jika ada suatu hal yang dapat dikoreksi dengan cara pandang yang berbeda tentu akan menambah suatu wawasan tentang kebenaran yang hakiki.

Disinilah letak kenapa logika memerankan peran yang sangat vital sebagai sebuah metode bernalar. Hal ini merupakan suatu rangkaian yang harus ditempuh sesuai hierarki tertentu guna memperoleh ilmu pengetahuan, serta mampu membuktikan benar atau tidaknya suatu hipotesis yang telah ada sebelumnya. ${ }^{7}$

\section{Model Proses (Metode) Penalaran}

a. Penalaran Deduktif

Penalalaran deduktif adalah suatu kerangka yang bertolak dari sebuah asumsi yang bersifat umum untuk mencapai kesimpulan yang bermakna lebih khusus. Pola penarikan kesimpulan dalam metode ini merujuk pada pola pikir yang biasa disebut dengan silogisme. Yang mana berawal dari suatu pernyataan atau lebih dengan sebuah kesimpulan dan kedua pernyataan tersebut sering disebut dengan premis mayor dan premis minor, serta diikuti dengan penyimpulan yang didapat melalui penalaran dari

4 Mundiri, 2000, Logika, Jakarta, Raja Grafindo Persada, hlm. 45-46

5 Mohammad Muslih, 2012, "Problem Keilmuan Kontemporer dan Pengaruhnya Terhadap Dunia Pendidikan", Tsaqafah Jurnal Peradaban Islam, Vol 8, hIm. 30.

6 Jujun S. Supriasumantri, 1993, Filsafat IImu: Sebuah Pengantar Populer, Yogyakarta, Karya Uni Press, hlm. 48.

7 Julia Branner, 2005, Memadu Metode Penelitian Kualitatif dan Kuantitatif, Samarinda, Pustaka Pelajar. 
kedua premis itu. Namun kesimpulan ini hanya bernilai benar jika kedua premis benar dan cara yang digunakan juga valid, serta hasilnya mengandung koherensi dari premis tersebut.

Kelebihan dari model ini terdapat pada faktor kebutuhan fokus yang intens dalam menganalisa suatu pengertian dari segi materinya, hal ini berpengaruh pada penggunaan waktu yang lebih efisien. Selain itu, pendekatan ini sesuai untuk digunakan dalam proses pembelajaran, dan adanya sifat dari deduksi di mana kesimpulannya merupakan suatu konsekuensi logis dari premis-premisnya. Jika premis benar, maka kesimpulan akan benar.

Adapun kelemahannya, terdapat pada aktivitas penarikan yang dibatasi pada ruang lingkup tertentu. Selain itu, jika salah satu dari kedua premisnya, atau bahkan semua premis salah, maka akan menimbulkan kesimpulan yang salah pula. Terlebih, kesimpulan yang diambil berdasarkan logika deduktif tak mungkin lebih luas dari premis awalnya, sehingga sulit diperoleh kemajuan ilmu pengetahuan jika hanya bertumpu pada logika deduktif saja.

b. Penalaran Induktif

Penalaran induktif adalah cara berpikir untuk menarik kesimpulan dari pengamatan terhadap hal yang bersifat umum atau universal. Penalaran induktif bertolak dari kenyataan yang bersifat terbatas dan khusus lalu diakhiri dengan pernyataan yang bersifat kompleks dan umum. ${ }^{8}$

Karakteristik dari penalaran induktif adalah adanya generalisasi. Generalisasi dapat dilakukan dengan dua metode yang berbeda. Pertama ialah induksi lengkap, dimana generalisasi yang dilakukan diawali hal-hal partikular yang mencakup keseluruhan jumlah dari suatu peristiwa yang diteliti. ${ }^{9} \quad$ Kedua, yang dilakukan dengan hanya sebagian hal partikular, atau bahkan dengan hanya sebuah hal khusus. Poin inilah yang biasa disebut dengan induksi tidak lengkap.

Induksi lengkap dicapai manakala seluruh kejadian atau premis awalnya telah diteliti dan diamati secara mendalam. Namun, jika tidak semua premis itu diamati secara teliti, maka diperolehlah induksi tidak lengkap. Bahkan ketika seseorang seusai mengamati suatu hal partikular lalu mengeneralisasikannya, maka sadar atau tidak, ia telah menggunakan induksi. Generalisasi di sini dapat benar atau salah, namun yang pentung adalah agar tidak terjadi kecerobohan generalisasi itu sendiri.

8 Jan Hendrik Rapar, Pengantar Logika: Asas-asas Penalaran Sistematis, Yogyakarta, Kanisius, hlm. 86.

9 Protasius Hardono Hadi dan T. Gallagher, 1994, Epistemologi, Filsafat Pengetahuan, Yogyakarta, Kanisius, hlm. 135 
Baik penalaran induktif atau deduktif memiliki kekurangan dan kelebihannya masing-masing. Namun perlu dipahami keduanya telah memberi corak cara berpikir ilmiah modern saat ini. Jika berpijak pada induktif saja maka ilmu pengetahuan akan berada pada kegelapan ilmiah begitu pula jika hanya pada deduktif belaka, maka ia tidak akan maju. Oleh karena itu, orang kemudian mencoba menggabungkan, memodifikasi dan mengembangkan keduanya menjadi sebuah sistem penalaran ilmiah modern saat ini, atau dalam istiah John Dewey disebut dengan berpikir reflektif. ${ }^{10}$ Dan langkah-langkah metode ilmiah itu dikemukakan oleh Anderson sebagai berikut: 1) Perumusan masalah. 2) Penyusunan hipotesis. 3) Melakukan eksperimen. 4) Pengumpulan dan pengolahan data. 5) Pengambilan kesimpulan. Dalam hal ini berarti ilmu memiliki kerangka penjelasan yang masuk akal serta menceriminkan kenyataan yang sebenarnya. ${ }^{11}$

\section{Upaya Memahami Realitas Hukum dengan Analisis Hukum yang Tepat}

Untuk memahami realitas hukum dengan penalaran hukum yang runtut dan sistematis, diperlukan langkah-langkah analisis hukum agar permasalahan hukum dapat terurai dan menghasilkan problem solving yang tepat. Ada lima langkah analisis hukum terkait dengan pemecahan masalah hukum, diantaranya:

a. Pengumpulan Fakta

Fakta hukum bisa berupa perbuatan, peristiwa, atau keadaan. Pembunuhan adalah perbuatan hukum, kelahiran adalah peristiwa hukum, dibawah umur adalah suatu keadaan. Pengumpulan fakta hukum didasarkan pada ketentuan tentang alat bukti.

b. Klasifikasi Hakikat Permasalahan

Klasifikasi hakikat permasalahan hukum pertama-tama berkaitan dengan pembagian hukum positif. Hukum positif diklasifikasikan atas hukum publik dan hukum privat yang masing-masingnya terdiri atas berbagai disiplin.

Hakikat permasalahan hukum dalam sistem peradilan kita terkait dengan lingkungan peradilan yang dalam penanganan perkara berkaitan dengan kompetensi absolut pengadilan.

c. Identifikasi dan Pemilihan Isu Hukum yang Relevan

Isu hukum berisi pertanyaan tentang fakta dan pertanyaan tentang hukum. Pertanyaan tentang fakta pada akhirnya menyimpulkan fakta hukum yang sebenarnya yang didukung oleh akat-alat bukti.

10 D. Van Dalen, 1973, Understanding Educational Research, New York, McGraw Hill Book Company, hlm. 13.

11 R.D. Anderson, 1970, Developing Children Thinking Through Science, New Jersey, Prentice-Hall, hlm. 5. 
d. Penemuan Hukum yang Berkaitan dengan Isu Hukum.

Dalam tradisi civil law, hukum utamanya adalah legislasi. Oleh karena itu, langkah dasar pola nalar yang dikenal sebagai reasoning based on rules adalah penelusuran peraturan perundang-undangan yaitu produk hukum tertulis yang dibuat oleh Lembaga negara atau pejabat yang berwenang, yang isinya mengikat umum. Lalu mengindentifikasi norma dan dilanjutkan dengan rechtsvinding. Fungsi rechtsvinding adalah menemukan norma konkret untuk diterapkan pada fakta hukum terkait.

e. Penerapan Hukum

Setelah menemukan norma konkret, langkah berikutnya adalah penerapan pada fakta hukum. Dalam hal ini pun tentu tetap menggunakan logika terkait dengan penerapannya. ${ }^{12}$

Sementara itu, Kenneth J. Vandevelde dalam pendapatnya mengatakan bahwa secara epistemologi penalaran hukum terdiri dari lima langkah, yaitu: ${ }^{13}$

a. Mengidentifikasi sumber hukum yang mungkin, biasanya berupa peraturan perundangundangan dan putusan pengadilan (identify the applicable sources of law).

b. Menganalisis sumber hukum tersebut untuk menerapkan aturan hukum yang mungkin dan kebijakan dalam aturan tersebut (analyze the souces of law).

c. Mensintesiskan aturan hukum tersebut ke dalam struktur yang koheran, yakni struktur yang mengelompokkan aturan- aturan khusus di bawah aturan umum (synthesize the applicable rules of law in to a coherent structure).

d. Menelaah fakta-fakta yang tersedia (research the available facts).

e. Menerapkan struktur aturan tersebut kepada fakta-fakta untuk memastikan hak atau kewajiban yang timbul dari fakta-fakta itu dengan menggunakan kebijakan yang terletak dalam aturan-aturan hukum dalam hal memecahkan kasus-kasus sulit (apply the structure of rules to the facts). ${ }^{8}$

Dalam diskursus filsafat, terdapat tiga aspek penting yang selalu muncul dalam pengkajian suatu objek. Ketiga aspek itu adalah kajian dari segi ontologis, epistemologis, dan aksiologisnya. Ketiganya dapat berlangsung secara komprehensif. Berikut ini adalah penjelasan tentang ketiga aspek dalam trilogi berpikir filsafat dalam menjelaskan realitas hukum:

12 Philipus M. Hadjon dan Titiek Sri Djatmiati, 2005, Argumentasi Hukum, Yogyakarta, Gadjah Mada University Press, hlm. 40-46.

13 Taqiuddin, Habibul Umam. 2017. "Penalaran Hukum (Legal Reasoning) Dalam Putusan Hakim", Jurnal Ilmu Sosial dan Pendidikan. Vol. 1. No. 2, hlm. 191-199. 


\section{a. Aspek Ontologis}

Kajian ontologis terhadap hakikat hukum secara garis besar dapat dipetakan kepada lima butir pengertian. Soetandyo Wignjosoebroto secara tepat menujukan kelima pemaknaan hakikat hukum itu, dengan mengartikan hukum sebagai: ${ }^{14}$

1) Asas-asas kebenaran dan keadilan yang bersifat kodrati dan berlaku universal;

2) Norma-norma positif dalam sistem perundang-undangan suatu negara;

3) Putusan hakim in-concreto, yang tersistematisasi sebagai judge made-law;

4) Pola-pola perilaku sosial yang terlembagakan, eksis sebagai variabel sosial yang empirik;

5) Manifestasi makna-makna simbolik para pelaku sosial sebagaimana tampak dalam interaksi di antara mereka.

Dalam model-model penalaran sebagai konstelasi kerangka orientasi berpikir yuridis, kelima aspek ontologis tentang hukum ini akan terlihat jelas. Masing-masing pengertian hukum berangkat dari asumsi-asumsi tersendiri

Hakikat hukum dapat diartikan sebagai asas-asas kebenaran dan keadilan yang bersifat kodrati dan berlaku universal. E. Sumaryono mengatakan "kebenaran hukum" di sini dapat dibaca sebagai "validitas hukum." ${ }^{15}$ dengan demikian hakikat hukum, baik dilihat dari aspek formalitasnya (validitas, keabsahan) maupun dari segi substansialnya (muatan keadilan) merupakan realitas kodrati. Pengertian ini berangkat dari asumsi bahwa segala sikap dan perilaku manusia dalam menjalani kehidupannya wajib tunduk pada suatu sistem moralitas yang bersifat kodrati. Sistem moralitas tadi kemudian mengalami internalisasi ke dalam diri manusia pribadi demi pribadi, sehingga akhirnya menjadi moralitas sosial.

\section{b. Aspek Epistemologis}

Aspek epistemologis berupa metode yang dimaksud dalam konteks ini adalah halhal yang terkait dengan cara-cara penarikan kesimpulan dalam proses penalaran hukum. pada galibnya, penalaran hukum (legal reasoning) direpresentasikan dengan mengikuti rangkaian proses bekerja (berpikir) seorang hakim (judicisl reasoning). ${ }^{16}$ Dengan demikian

14 Soetandyo Wignjosoebroto, Konsep Hukum, Tipe Kajian dan Metode Penelitiannya", Makalah disampaikan pada Penataran Metodologi Penelitian Hukum di Fakultas Hukum Unhas: Makasar, 4-5 Februari 1994, hlm. 2-3.

15 E. Sumaryono, 2002, Etika dan Hukum: Relevansi Teori Hukum Kodrat Thomas Aquinas, Yogyakarta, Kanisius, hlm. 79.

16 A. Hamid S. Attamimi, 1998, "Pengantar," dalam Maria Farida Indrati Soepratpto, IImu Perundangundangan: Dasar-Dasar dan Pembentukannya, Yogyakarta; Kanisius, hlm. xv-xxv. 
pengertian penalaran hukum telah dipersempit menjadi penalaran hakim tatkala yang bersangkutan menghadapi suatu kasus konkret.

Sudikno Mertokusumo mengatakan bahwa seorang sarjana hukum, khususnya hakim, selayaknya menguasai kemampuan menyelesaikan perkara yuridis (the power of solving legal problems), yang terdiri dari tiga kegiatan utama yakni merumuskan masalah hukum (legal problem identification), memecahkannya (legal problem solving), dan terakhir mengambil keputusan (dicision making). ${ }^{17}$

\section{c. Aspek Aksiologis}

Uraian mengenai aspek aksiologis dalam hal ini, berhubungan dengan tujuan dari aktivitas penalaran hukum. diyakini bahwa penalaran hukum tidak dilakukan semata-mata untuk penalaran itu sendiri. William Zelermyer juga mengingatkan, bahwa dalam penalaran hukum: ${ }^{18}$

We are dealing with human beings and not with things. We must reasonable. This means that the law and its decisions must be supported by reason; they must be the products of arbitrary action. To be reasonable does not necessarily mean to be logical. Logic can lead to injustice, hence we must guard against its abusieve use.

Ucapan tersebut memberikan konfirmasi tentang aspek aksiologis dari penalaran hukum. ada tujuan-tujuan yang ingin dicapai dalam penalaran hukum agar penalaran tadi tidak disalahgunakan, sehingga akhirnya justru bertentangan dengan prinsip-prinsip hukum itu sendiri.

\section{Simpulan}

Pemahaman mengenai realitas hukum bukanlah suatu yang sederhana. Penalaran memiliki peran dalam memahami realitas hukum untuk senantiasa berada pada jalur pemikiran yang logis dan metode yang analitis.

Pembelajar hukum memegang andil yang besar dalam memahami realitas hukum sekaligus menghadirkan solusi atas realitas hukum yang terjadi dalam konteks kehidupan hukum di negara kita. Melalui berbagai profesi penegak hukum, mereka nantinya akan menjadi penentu dalam merepresentasikan 'wajah hukum' bangsa Indonesia. Untuk memahami realitas hukum secara tepat, pembelajar hukum perlu melakukan penalaran hukum maupun menerapkannya melalui langkah-langkah analisis hukum terkait dengan penyelesaian masalah

17 Sudikno Mertokusumo, Penalaran Hukum di Indonesia dalam Sorotan, Harian Kompas, 7 November 1990, hlm. 4 \& 5.

18 William Zelermyer, 1960, Legal Reasoning: The Evolutionary Process of Law, Englewood Cliffs: Prentice-Hall, hlm. 4. 
hukum, sehingga diharapkan dapat lebih bijak dalam menghadapi perbedaan pemahaman yang ada di masyarakat dan dapat memberikan argumennya terkait fenomena tersebut secara logis dan nalar. Oleh karena itu, penalaran menjadi hal yang vital dalam memahami hukum maupun fenomena yang berkaitan dengannya. Penalaran hukum merupakan bagian dari landasan berpikir positivisme. Penalaran menjadikan pemahaman hukum begitu rupa rasional sehingga melahirkan sifat hukum yang objektif, baik dalam kerangka paradigma positivisme maupun paradigma post-positivisme.

Dari uraian singkat di atas dapat disimpulkan bahwa penerapan hukum tertulis memerlukan penafsiran, penalaran dan argumentasi hukum yang rasional agar senantiasa dapat mengikuti perubahan dan perkembangan masyarakat. Dalam diskursus filsafat, terdapat tiga aspek penting yang selalu muncul dalam pengkajian suatu objek. Ketiga aspek itu adalah kajian dari segi ontologis, epistemologis, dan aksiologisnya yang dapat berlangsung secara komprehensif.

\section{DAFTAR PUSTAKA}

Anderson, R.D., 1970, Developing Children Thinking Through Science, New Jersey, PrenticeHall.

Branner, Julia, 2005, Memadu Metode Penelitian Kualitatif dan Kuantitatif, Samarinda, Pustaka Pelajar.

Dalen, D. Van, 1973, Understanding Educational Research, New York, McGraw Hill Book Company.

Hadi, Protasius Hardono dan Gallagher, Kenneth T., 1994, Epistemologi Filsafat Pengetahuan, Yogyakarta, Kanisius.

M. Hadjon, Philipus, Djatmiati, Titiek Sri, 2005, Argumentasi Hukum, Yogyakarta, Gadjah Mada University Press.

Mertokusumo, Sudikno, Penalaran Hukum di Indonesia dalam Sorotan, Harian Kompas, 7 November 1990.

Mundiri, 2000, Logika, Raja Grafindo Persada, Jakarta.

Muslih, Mohammad, 2012, "Problem Keilmuan Kontemporer dan Pengaruhnya Terhadap Dunia Pendidikan”, Tsaqafah Jurnal Peradaban Islam, Vol 8.

Mustofa, Imron, 2016, "Jendela Logika dalam Berfikir: Deduksi dan Induksi sebagai Dasar Penalaran IImiah”, Jurnal El-Banat, Vol. 6.

Rapar, Jan Hendrik Rapar, 1996, Pengantar Logika: Asas-asas Penalaran Sistematis, Yogyakarta, Kanisius.

Shidarta, 2013, Hukum Penalaran dan Penalaran Hukum, Yogyakarta, Genta Publishing. 
Simanjuntak, Nikolas, 2009, Acara Pidana Indonesia Dalam Sirkus Hukum, Jakarta, Ghalia Indonesia.

Sumaryono, E., 2002, Etika dan Hukum: Relevansi Teori Hukum Kodrat Thomas Aquinas, Yogyakarta, Kanisius.

Supriasumantri, Jujun S., 1993, Filsafat Ilmu: Sebuah Pengantar Populer, Yogyakarta, Karya Uni Press.

Taqiuddin \& Umam, Habibul, 2017. "Penalaran Hukum (Legal Reasoning) Dalam Putusan Hakim", Jurnal IImu Sosial dan Pendidikan, Vol. 1. No. 2.

Wignjosoebroto, Soetandyo. "Konsep Hukum, Tipe Kajian dan Metode Penelitiannya." Makalah disampaikan pada Penataran Metodologi Penelitian Hukum di Fakultas Hukum Unhas: Makasar, 4-5 Februari 1994.

Zelermyer, William, 1960, Legal Reasoning: The Evolutionary Process of Law, Englewood Cliffs, Prentice-Hall. 